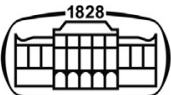

AKADÉMIAI KIADÓ

\title{
Correlation between military and domestic architecture: A tribune's house in Aquincum and its place in Roman architecture
}

\section{Acta Archaeologica Academiae Scientiarum Hungaricae}

72 (2021) 2, 267-277

DOI:

$10.1556 / 072.2021 .00016$

(c) 2021 The Author(s)
ORIGINAL RESEARCH PAPER

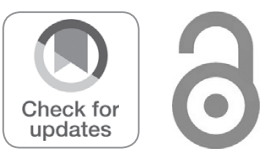

*Corresponding author. E-mail: timar.lor@gmail.com
Lőrinc Timár* ๑

MTA-ELTE Research Group for Interdisciplinary Archaeology, Múzeum krt. 4/B, H-1088, Budapest, Hungary

Received: March 17, 2021 • Accepted: June 22, 2021

\section{ABSTRACT}

The House of the Tribunus Laticlavius, a large building in the legionary fortress of Aquincum, has only been partially excavated, and this was in the 1970s. This short paper makes an attempt to understand its function and find its place in Roman architecture through a reconstruction of its floor plan and comparison with other prominent residential buildings of the period which share similar features. It appears very likely that the house is based on a loose adaptation of a Hellenistic model, tailored to the needs of high-ranking officers of the Roman army.

\section{KEYWORDS}

Roman architecture, Pannonia, Aquincum, domus, peristyle house, legionary fortress

In the present paper we will examine a specific building and its possible architectural roots: an officer's house from the legionary fortress of Aquincum in Lower Pannonia. Since the excavations could not explore the full extent of this building, its floor plan is incomplete. However, there are some conclusions which can be ascertained from the information that we have at present, as will be discussed in the following.

The House of the Tribunus Laticlavius (Fig. 1) inside the fortress of the Legio II Adiutrix was excavated in 1978-79. ${ }^{1}$ Preceded by an early fortress during Domitian's reign, the legionary fortress of Aquincum was built under Hadrian, and was partially rebuilt after AD 260. It was extensively remodelled in the late Roman period. ${ }^{2}$ We can surmise from the finds that the house had its heyday in the second and third centuries $\mathrm{AD}$, although it was still in use in the legionary fortress's late phases. ${ }^{3}$ Although the preliminary report of the excavations is rather succinct, we know the outlines of the house's floor plan and its main features. ${ }^{4}$ The house of $59.5 \times 39.5 \mathrm{~m}\left(200 \times 130\right.$ Roman feet, $\left.2,350 \mathrm{~m}^{2}\right)$ occupied half of an insula along the via principalis, and it was flanked by a porticus and a row of tabernae on its western side, according to archaeologist L. Kocsis. ${ }^{5}$ He supposed that the entrance was in the middle of this western façade. ${ }^{6}$ The house's rooms were organized around a peristyle (3), where foundations of altars have survived which were placed along its western side. Two displaced altar stones were found lying on the ground of the courtyard. ${ }^{7}$ Some of the rooms around the peristyle have been excavated, notably a group of rooms with hypocaust (1), a Mithraeum (2) which was built around the turn of the second and third centuries $\mathrm{AD}$, and a large room, apparently

${ }^{1}$ Kocsis (1991) 117

${ }^{2}$ Németh (2003) 99-101.

${ }^{3}$ Kocsis (1991) 141-142.

${ }^{4}$ According to the opinion of Kocsis it resembles the house of the tribunus laticlavius of Vidonissa: Kocsis (1991) 145, footnote 4. He refers there to Petrikovits (1975) Abb. 12/6.

${ }^{5}$ Kocsis (1991) 117.

${ }^{6}$ See the floor plan and the interpretation in Kocsis (1991) 159-160.

${ }^{7}$ Altars 9 and 10: Kocsis (1991) 120. 

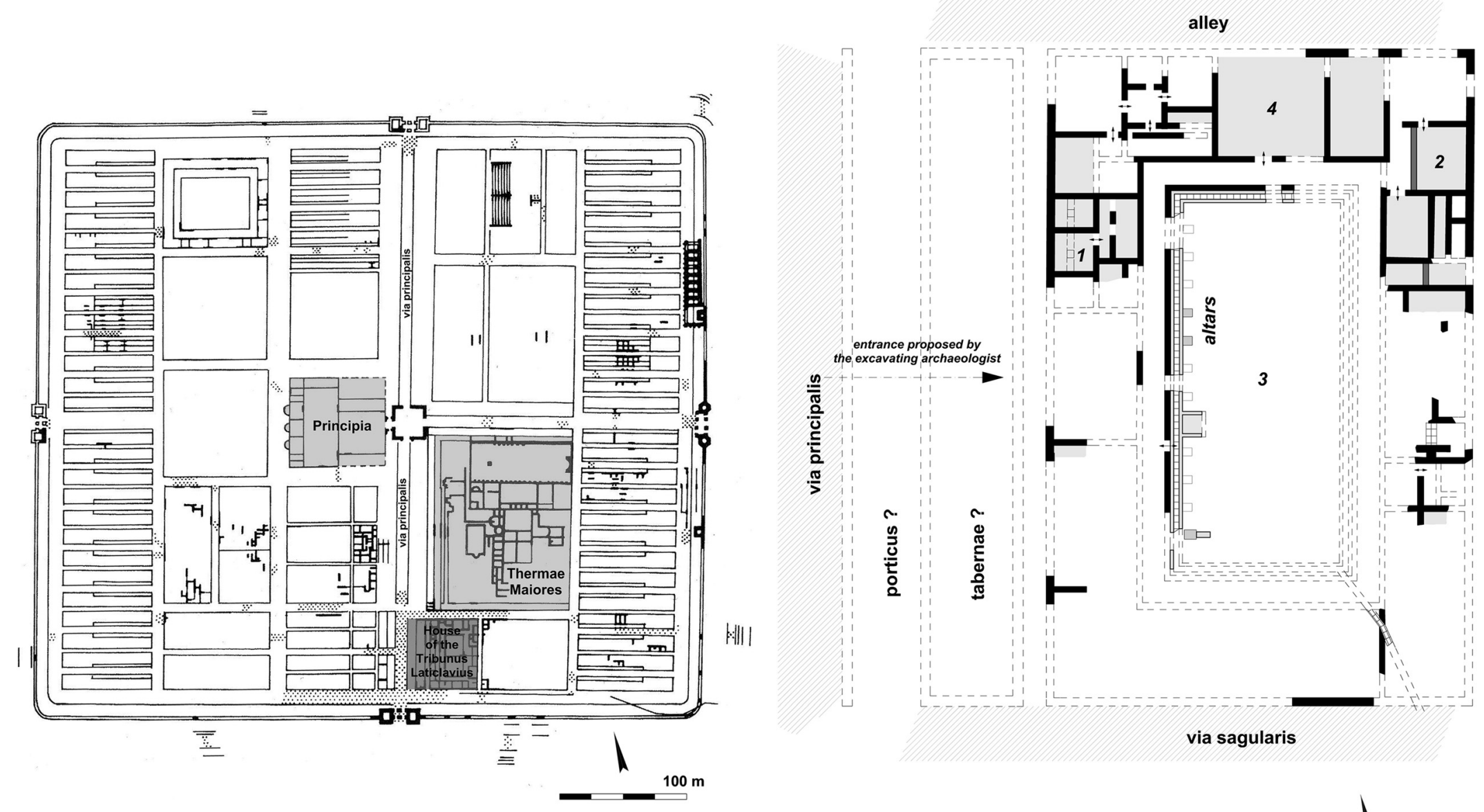

Fig. 1. The legionary fortress of Aquincum (after Németh, 2003) and the House of the Tribunus Laticlavius (after Kocsis, 1991)

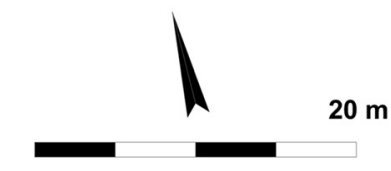


a reception room, on the courtyard's longer axis (4). In the Mithraeum, an inscription and six altar stones were found in situ. The house's western and southern parts are largely unexplored. Even though the floor plan is incomplete, we can still draw a comparison between this house and a specific urban residential house type.

The arrangement of an oblong courtyard with a large axial room facing southwards derives from a very old architectural model. Although the houses in Roman military fortresses are usually treated as belonging to military architecture, some of them show features which can also be found in Roman town houses. This relationship between houses in civilian and military contexts is often overlooked, even though it is well known that retired soldiers played an important role in Roman society. Former army architects were involved at all levels of municipal construction works, which obviously leads to the transmission of architectural knowledge and practices. ${ }^{8}$ We will make no distinction here between architect and engineer, although there was a certain degree of specialisation. ${ }^{9}$ Note that there also seems to have been some overlap between engineers and mathematicians, especially in the construction of domes. ${ }^{10}$ Besides transferring utilitarian information this connection also resulted in architectural innovations related to luxury. A report of Cornelius Nepos, cited by Pliny the Elder ${ }^{11}$ mentions that Mamurra, a former praefectus fabrum of Caesar's army, was the first to cover his house with marble slabs, and the first in Rome to build solid marble columns in his house. Using solid stone for wall cladding and columns was already a common practice in the architecture of public buildings. The novelty here was their use in a domus. Pliny also records that M. Scaurus took the extremely expensive decoration from his temporary theatre and transported it to his villa in Tusculum. ${ }^{12}$ Military campaigns seem to have been important sources of foreign architectural influence in Rome. Perhaps the most prominent example was Pompey's decision to build a larger version of the theatre of Mytilene in Rome. ${ }^{13}$

Where should we search for the origins of the floor plan of the House of the Tribunus Laticlavius? It seems to be quite reasonable to start from the Palazzo delle Colonne, which was a large and complex building in Ptolemais in Cyrenaica (stretching over an area of $37 \times 90 \mathrm{~m}$, Fig. 2). Its function and the date of its construction have been much debated and we must note that the palace was remodelled many times; but the floor plan and the decoration of the house is definitely Hellenistic, from the second century BC, and derived from Alexandrian architecture. ${ }^{14}$ The palace also corresponds to the plan of the Greek house described by

\footnotetext{
${ }^{8}$ Gros (1994) 79-81.

${ }^{9}$ Gros (1983) 428 and 433.

${ }^{10}$ McKenzie (2007) 322-327.

${ }^{11}$ Nat.Hist. 36, 7.

${ }^{12}$ Nat.Hist. 36, 24.

${ }^{13}$ Plut., Pomp. 42

${ }^{14}$ McKenzie (2007) 97-98 and 153.
}

Vitruvius in his De architectura VI,7. ${ }^{15}$ The core of this house was made up of three units: an entrance hall, a courtyard and a reception hall, with all three placed along the longitudinal axis. The entrance hall had an internal quadriporticus, similar to that of Vitruvius' oecus Corinthicus and Aegypticus. ${ }^{16}$

This suite of entrance hall, courtyard (peristyle), and reception hall is found in a number of houses and palaces. During the time of the transition between Roman Republic and the Empire, a resized and simplified form of this suite of rooms, called la trilogie publique by French researchers ${ }^{17}$ became very popular in a particular peristyle house type.

Particularly noteworthy in this context is the Casa dei Cervi (IV.21) from Herculaneum, a paradigmatic example which was followed by many provincial derivatives. The Casa dei Cervi is dated to the first decades $\mathrm{AD}$ by J.-A. Dickmann ${ }^{18}$ - although L. Richardson suggests a slightly later dating, ${ }^{19}$ while P. Gros proposes an earlier construction date. ${ }^{20}$ It was undoubtedly a modern house in its time, ${ }^{21}$ as the atrium became outdated by the middle of the first century $\mathrm{AD}$ in both Gaul and Northern Italy. ${ }^{22}$ Along its longitudinal axis we see an entrance room at the southern end, followed by a large hall with two flanking rooms (this part of the configuration is styled as a "Dreiraumgruppe unit" ${ }^{23}$ ), protruding into the peristyle garden. At the other end of the house's longitudinal axis we find a cenatio, or dining room. This typical arrangement, with a hall, courtyard and dining room along an axis, can be considered a loose adaptation of the axial Hellenistic palace type. The Casa dei Cervi had an intricate interior, with alternating open and closed spaces, lavish decoration and coherent symmetry: these features of course had Hellenistic roots, but their rendering was characteristically Roman. It is important to note that the Casa dei Cervi's axis was directed towards the view to the sea, and this is significant in analysing its layout and comparing it with other town houses which lacked the possibility of this feature.

In the first decades of the first century $\mathrm{AD}$ a number of similar houses were built in Southern Gaul. We may refer here to the Maison de Dieu Marin ${ }^{24}$ and two more houses both named Maison au Grand Péristyle, ${ }^{25}$ all three of which

\footnotetext{
${ }^{15}$ Raeder (1988) 367.

${ }^{16}$ Vitruv., Arch. VI, 3, 8-10.

${ }^{17}$ Vipard et al. (2007) 239-249.

${ }^{18}$ Dickmann (1999) 329-330, and see also footnote 168 therein.

${ }^{19}$ Richardson (1997) 354

${ }^{20}$ Gros (2001) 67.

${ }^{21}$ Richardson (1997) 354-355.

${ }^{22}$ Vipard et al. (2007); 239, Timár (2011), 60; George (1997), 3; Bonini (2013) 46-47.

${ }^{23}$ Dickmann (1999) 322.

${ }^{24}$ Atlas (1996); Rouard (1844): Aix, fiche nr. 14, CAG 13/4, 297, 298.

${ }^{25}$ Enclos Milhaud: Atlas (1996); Rouard (1841): Aix, fiche nr. 10, CAG 13/4, 301-303; Jardin de Grassi: Atlas (1996) 31: fiche nr. 7, CAG 13/4, 287, Fig. 278.
} 


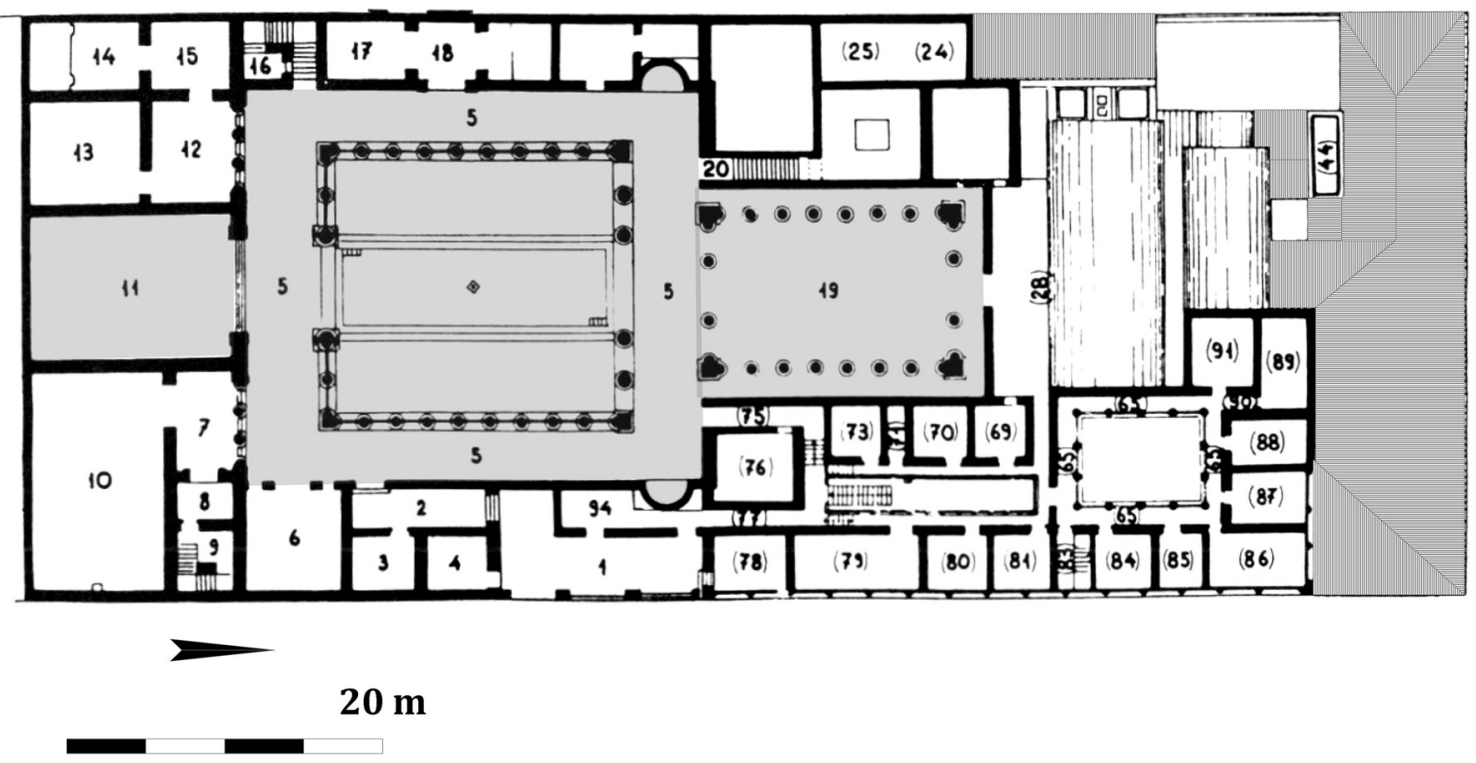

Fig. 2. The Palazzo delle Colonne in Ptolemais, plan of the first floor. Entrance hall (19), peristyle (5) and reception hall (11) are highlighted in grey. After Raeder (1988)

are in Aix-en-Provence, and the Maison à l'Emblema de Lion $^{26}$ in Limoges. Their known floor plans (Fig. 3) are very fragmentary and little of their decoration has survived. Nevertheless, it is still possible to discern that the houses lacked an atrium, but had an oblong courtyard and cenatio (sometimes being part of a Dreiraumgruppe unit) arranged longitudinally. It should also be noted that they are about the same size: each cover a plot of approx. $30 \times 90 \mathrm{~m}(100 \times$ 300 feet).

In the following centuries, peristyle houses in Gaul seem to have been restricted to the provincial elite. ${ }^{27} \mathrm{~A}$ later example is the Maison des Dieux Océan ${ }^{28}$ in Vienne (Colonia Iulia Vienna), which underwent several transformations during its existence. Its third and fourth phases are of special interest here. In its third phase, dated to Neronian or Flavian times, its southern façade was flanked by a porticus (Fig. 4). From the entrance porch (1) there opened a huge reception hall of $154 \mathrm{~m}^{2}$, which presumably had a mosaic floor. In the hall's centre there were eight column or pillar bases in two rows and an impluvium in the middle: an arrangement which does not correspond to any of the atrium types but corresponds to the oecus Corinthicus described by Vitruvius. The hall there was followed by a peristyle garden or a courtyard (13) with a pool. Room 14 on the peristyle's longitudinal axis opened onto the peristyle, while room 20 behind it opened onto the back garden.

In the second half of the second century $\mathrm{AD}$ the house was slightly remodelled in its fourth phase. ${ }^{29}$ The entrance

\footnotetext{
${ }^{26}$ Loustaud (2000) 191-193.

${ }^{27}$ Vipard et al. (2007) 229-230.

${ }^{28}$ Atlas (1996) 372-375, Desbat et al. (1994) 140-159.

${ }^{29}$ Desbat et al. (1994) 172-180.
}

hall (A) became simplified, the peristyle's pool (B) was reshaped, and smaller rooms in the house's central part were merged together into one large hall $(\mathrm{C})$, which also opened towards the grand second peristyle (D). As there were no small cubicula in the house, one can also presume that in its fourth phase it was a collegium, ${ }^{30}$ but this hypothesis cannot be conclusively established due to the lack of epigraphic evidence. There is little difference between these peristyle houses and the complex collegial building type represented by the Schola del Traiano in Ostia, dated to the middle of the second century $\mathrm{AD},{ }^{31}$ as all of them had similar functions. Banquets were held in these collegial buildings, and servants could be accommodated there as well. There were also functional differences which were not necessarily reflected in the architectural framework. ${ }^{32}$ As Roman houses always had some sort of public function, many of their rooms were used for the reception of clients or guests, and consequently there were no distinct, specific floor plans for houses, palaces or offices. Tacitus mentions strangers coming to Agricola's house and asking for news, which must have been a common practice. ${ }^{33}$ Furthermore, Roman houses had public and private parts which are not always easy to distinguish. ${ }^{34}$ A daily salutatio in the house of a wealthy and honourable Roman aristocrat like Aemilius Scaurus, whose house had an immense atrium ${ }^{35}$ perhaps needed an even larger room than the emperor's court of justice in his villa near

\footnotetext{
${ }^{30}$ Bouet (2001) 256.

${ }^{31}$ Bollmann (1998) 58-72.

${ }^{32}$ Bouet (2001) 274-278.

${ }^{33}$ Tacit., Agr. 43.

${ }^{34}$ Wallace-Hardill (1994) 38-61.

${ }^{35}$ Gros (2001) 75.
} 


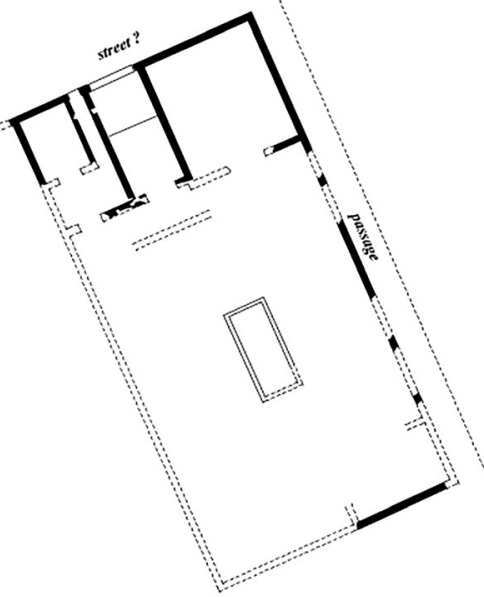

Aix-en-Provence, Enclos Milhaud Maison du Dieu Marin

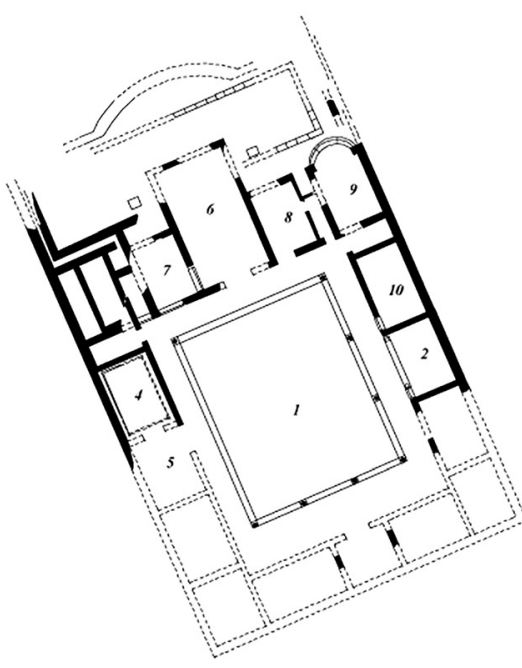

Aix-en-Provence, Jardin de Grassi Maison au Grand Péristyle

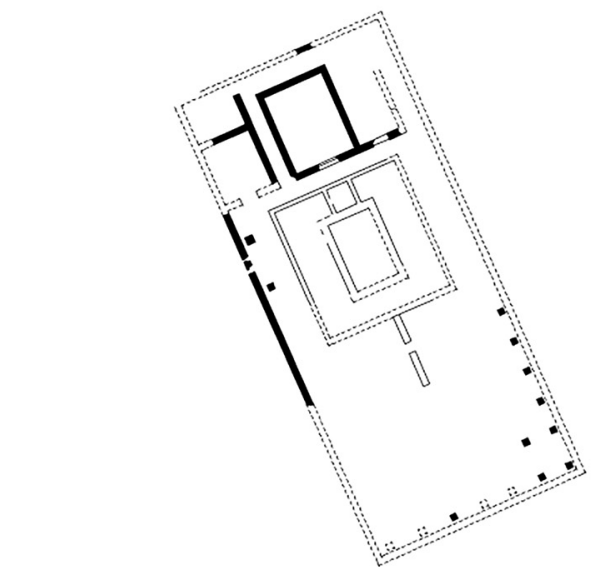

Aix-en-Provence, Enclos Milhaud Maison au Grand Péristyle
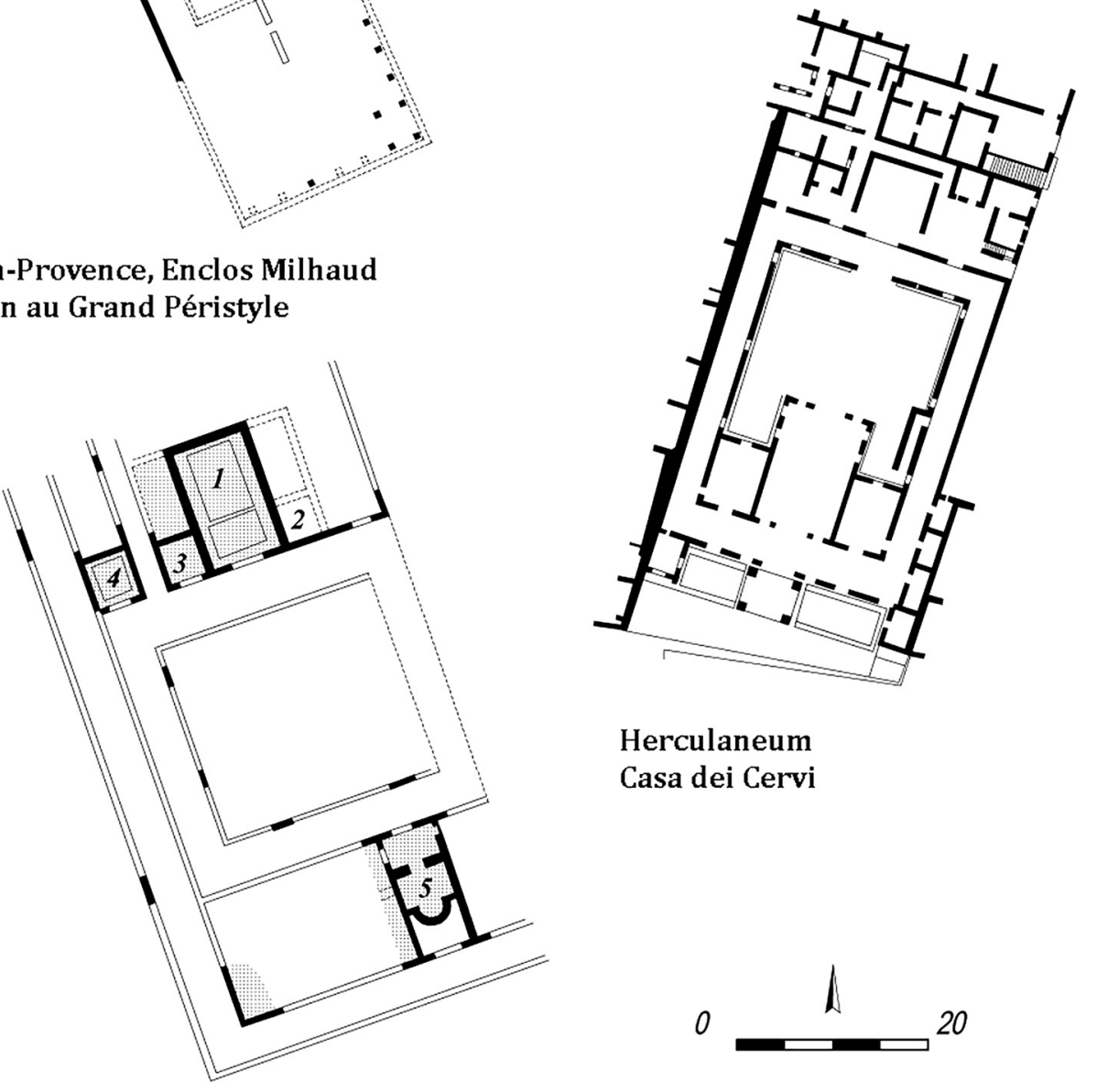

Herculaneum

Casa dei Cervi

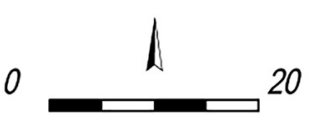

Maison à l'Emblema de Lion

Fig. 3. The Casa dei Cervi and some similar provincial houses from Gaul. Note that the houses are all drawn to the same scale and have the same orientation. After Timár (2011) 


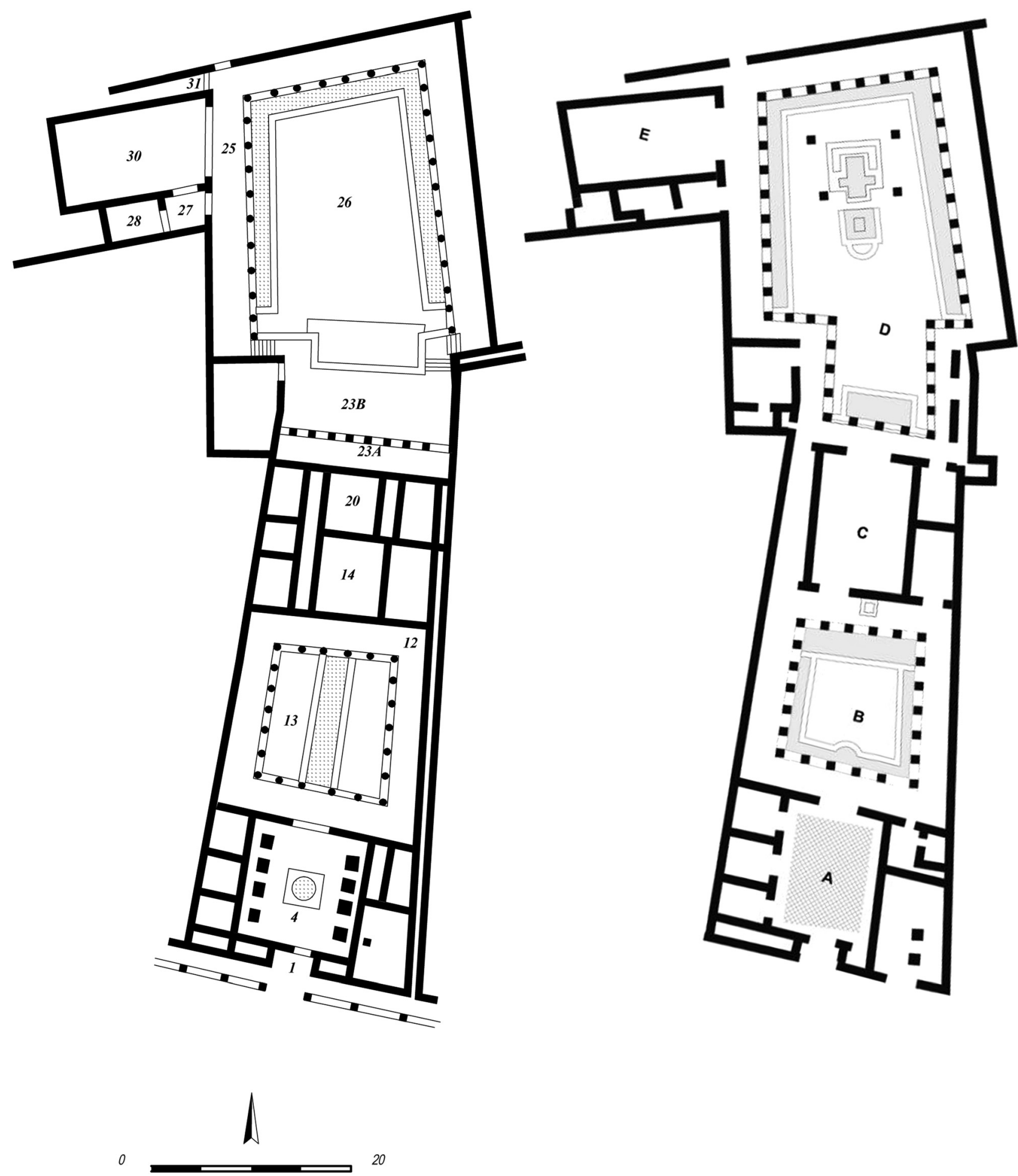

Fig. 4. Maison des Dieux Océan, third (left) and fourth (right) phases. After Desbat et al. (1994)

Centum Cellae. ${ }^{36}$ Even though the Maison des Dieux Océan's peristyle is different from those of the other houses we have shown above, the entrance hall-peristylereception room sequence was retained in both its third

${ }^{36}$ Plin., Epist. 6,31. and fourth phases. Although the rendering is simplified, the legacy of the Hellenistic concept is still obvious.

With the decline of the provincial aristocracy, peristyle houses in urban contexts were abandoned in Gaul by the end of the third century AD. ${ }^{37}$ It is not easy to assess the 


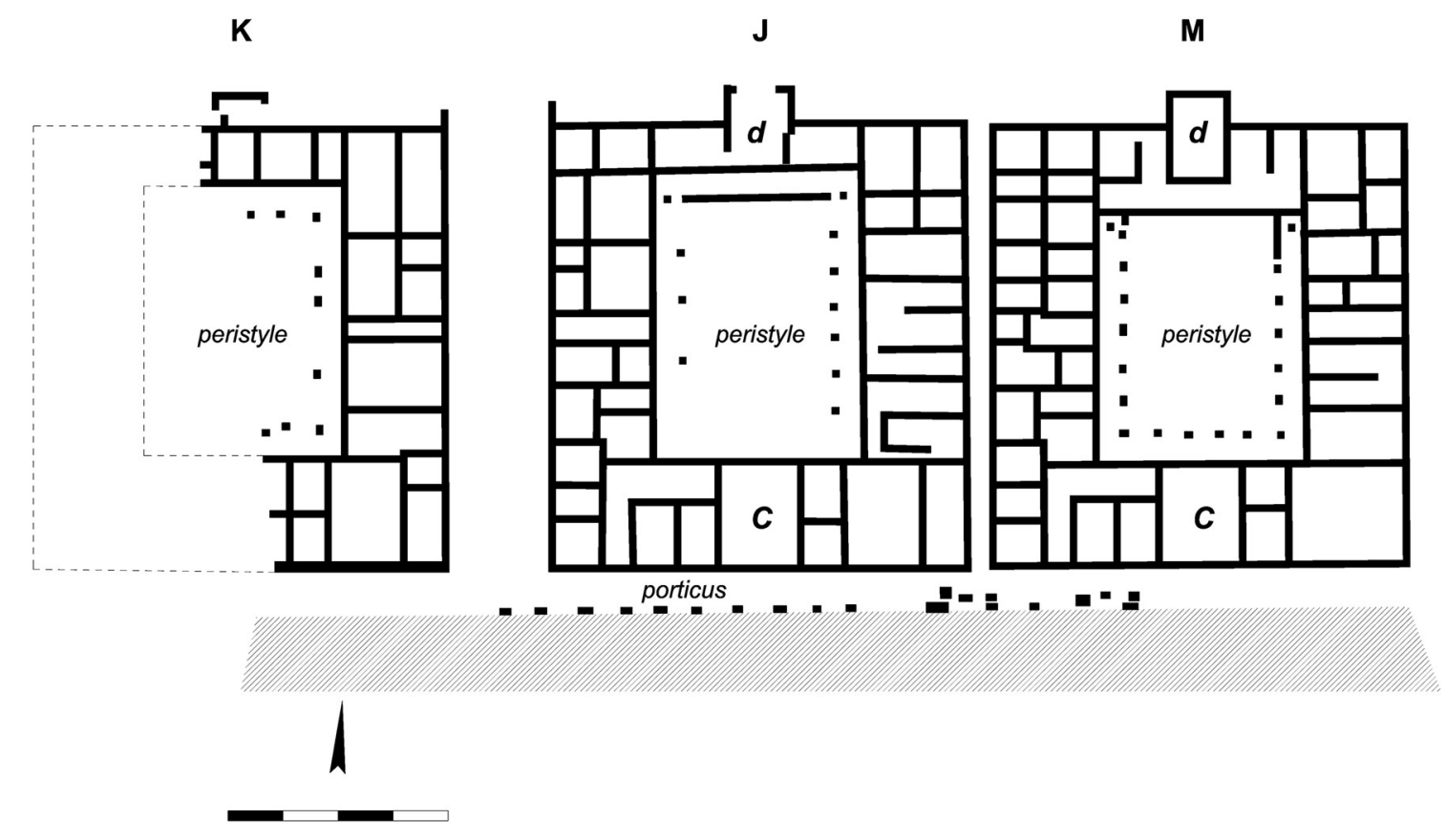

Fig. 5. Officers' houses from Vetera, after Lehner (1927)

situation in Pannonia because in towns only a few peristyle houses are known at all. One of them, the so-called palatium of Gorsium, was an axial peristyle house built in the fourth century. The earlier excavations did not reveal the surroundings of the building, which was for a long time thought to be a villa. ${ }^{38}$ Its floor plan clearly shows the entrance hallperistyle-reception hall configuration. Another example is stone house nr. 2 from the municipium of Mursella, built around the middle of the third century ${ }^{39}$ and occupying an area of $43 \times 43 \mathrm{~m}$. Its peristyle was rectangular, with two larger rooms on opposite sides of the peristyle which can be interpreted as reception room and entrance hall. ${ }^{40}$

We also find this triple suite in houses within military fortresses, although they were restricted to the houses of high-ranking officers. As the decoration of the rooms has not survived, our considerations must depend only on the layout of the floor plans. The triple suite can be observed in the floor plan of two identical houses (Fig. 5) from the fortress Vetera I at Xanten. ${ }^{41}$ Houses J and M both have an entrance hall (c), a peristyle, and a dining room (d) partially protruding from the houses' back walls. House $\mathrm{K}$, whose remains are less complete, was presumably identical to the two others. These houses existed until the fortress was destroyed during the revolt of the Batavi in $70 \mathrm{AD}$.

A slightly different but related house type (Fig. 6) is represented by the tribunes' houses of Inchtuthil. ${ }^{42}$ These houses had oblong peristyles and their dining rooms (d)

\footnotetext{
${ }^{38}$ Thomas (1955) 86-88; Fitz (1976) 100.

${ }^{39}$ Szőnyi (2008) 241.

${ }^{40}$ Szőnyi (2008) 239-240 and 239, Abb. 7.

${ }^{41}$ Lehner (1927) 613 and 614, Abb. 2.

${ }^{42}$ Pitts and St. Joseph (1985) 129-141.
}

were positioned on the northern side, facing south. Their relatively modest vestibules were placed off the house's primary axis. Offices - series of small rooms opening off a corridor - adjoined the narrow sides of the houses (B). Although these houses are not axial peristyle houses, they nevertheless retain all the important components of those buildings. The fortress of Inchtuthil existed probably only between 83 and $86 \mathrm{AD}^{43}$ which means the house type must have still been in fashion by the last quarter of the first century.

These officers' houses must have fulfilled various functions: administrative, residential and representative. Their similarity to the town houses, and particularly the presence of a peristyle, implies that the underlying architectural concept was to provide spaces for social interaction and also for some amenities which were typical of the Roman upper classes. The inscriptions found in the House of the Tribunus Laticlavius in Aquincum (most of them on altars) have preserved the names of some tribuni laticlavi, and at least two of them ended their careers as consuls. For men of such social standing, even though their rank was only the first along a cursus honorum, it must have been almost compulsory to live in a house within the military fortress which was suitable for a Roman aristocrat. There is hardly any other way we can interpret these floor plans. These officers' houses were not the property of their occupants, who spent a relatively short time of their military service there: they were meant to accommodate whoever filled a particular rank. The houses reflect the architectural fashion of the time when they were built, rather than when they were used, and they might not have been regularly upgraded or rebuilt in

${ }^{43}$ Pitts and St. Joseph (1985) 31. 
house I

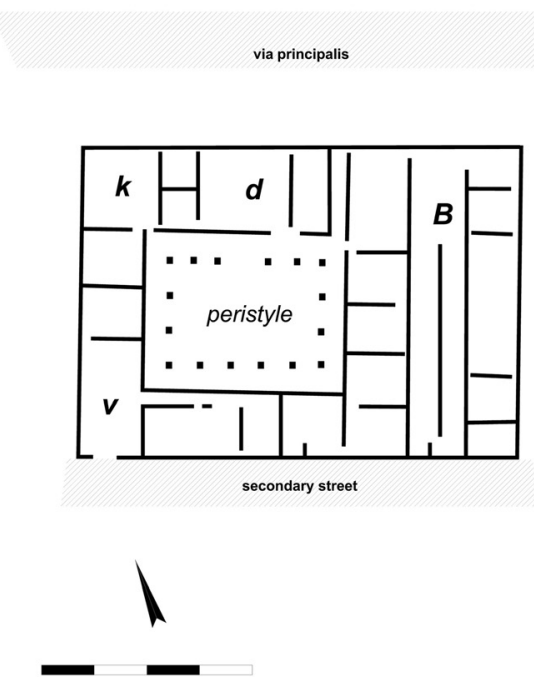

house III

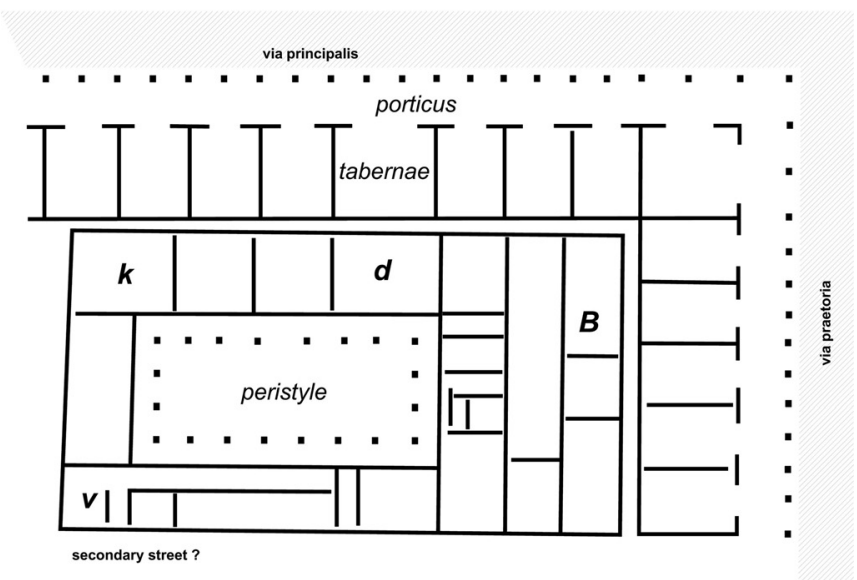

Fig. 6. Tribunes' houses from Inchtuthil. After Pitts and St. Joseph (1985)

their later years. Archaeology cannot reveal all the details, but we can imagine an ageing yet more or less well-maintained colonial officers' house of a hundred years old or so, which still offered some extra comfort and prestige inside an austere military fortress.

After this discursion it is time to turn back to the architecture of the House of the Tribunus Laticlavius, which saw some renovation in Severan times when it gained a Mithraeum, from which important wall paintings have survived. ${ }^{44}$ From the interpretation of its floor plan we can draw the following conclusions. All the Roman houses we have reviewed have their dining or reception rooms on the northern side of their peristyle, with the dining or reception room doors facing south. Consequently, the houses' vestibule or entrance is on the peristyle's southern side, and these vestibules are usually larger halls. The entrance hall-peristyle-reception room suites are arranged axially, with the exception of the houses from Inchtuthil. In these latter houses the office rooms were placed on the peristyles' eastern side, and they could be accessed through a long corridor. They seem to have had their own entrance separate from the residential part.

It should be noted that the houses of Inchtuthil seem to have been cut off from the main streets of the military fortress, and so have the seemingly odd feature that they were accessible from small secondary streets only. The reason for this seems to be simple. As usual, the legionary fortress of Inchtuthil faced the enemy, which means that its porta praetoria faced north in this case. The tribunes' houses were placed on the side of the via principalis opposite to the porta praetoria. Therefore, the houses' façade also faced north. However, it was of paramount importance that the dining rooms of these houses face south (cf. Vitruvius IV, 12). Consequently the builders of the houses had to rotate the

${ }^{44}$ Madarassy (1991) 123-126, 154 and 165-168. floor plan and place the dining rooms on the side near the main street, while the entrance had to be placed opposite to the dining room, following the Hellenistic pattern.

It is apparent that the legionary fortresses' orthogonal plan and the compulsory placement of the officers' houses along lateral streets meant significant constraints on the design of the individual houses. The houses in the legionary fortress of Vetera had a straightforward floor plan because the fortress's porta praetoria faced south (Fig. 7).

The legionary fortress of Aquincum had its porta praetoria directed towards east. The House of the Tribunus Laticlavius' floor plan had to conform to the via principalis directed north to south. Its main reception room had to be placed on the peristyle's northern side as it had to face south. It was suggested in the excavation report that the entrance was on the house's western side, but this seems unlikely. Since the reception room and the oblong peristyle have the same axis, there is little reason to suppose that the entrance was placed off that line. Furthermore, the altar bases found in situ were arranged along the peristyle's long side and thus would have been hidden from a visitor entering the peristyle from the west. If the entrance was on the southern side of the peristyle, as shown in Fig. 8, the altars (and perhaps their symmetrical counterparts on the peristyle's eastern side) would have been part of the vista through the building, which was also an important feature of the Roman domus. The example of the Casa dell'Atrio a Mosaico in Herculaneum clearly shows how significant the vista was in the design of a house's interior. ${ }^{45}$ By the beginning of the Imperial Era much of a house's decoration was subordinated to it, especially when sculptures and wellheads were demoted to serving as garden decoration set up in pairs along the buildings' main axis. ${ }^{46}$

\footnotetext{
${ }^{45}$ Wallace-Hadrill (1994) 18-20, 127 and 128, Fig. 6.6-7.

${ }^{46}$ Dickmann (1999) 355-358 and 364-369.
} 


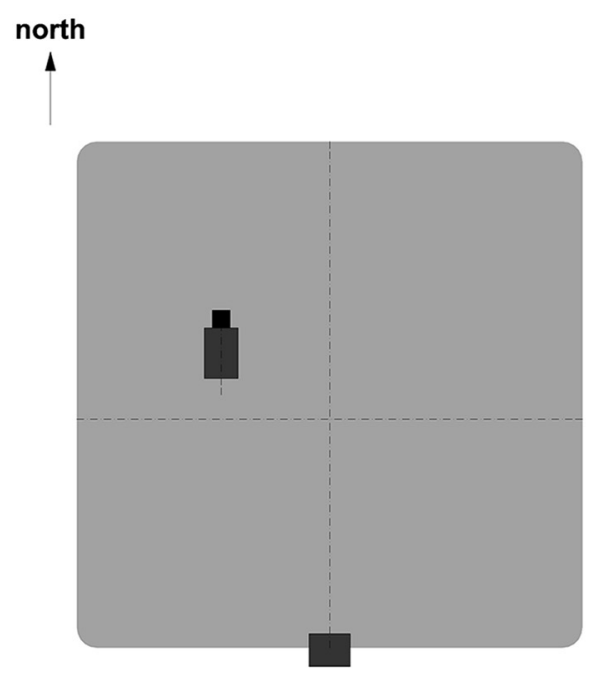

Vetera I

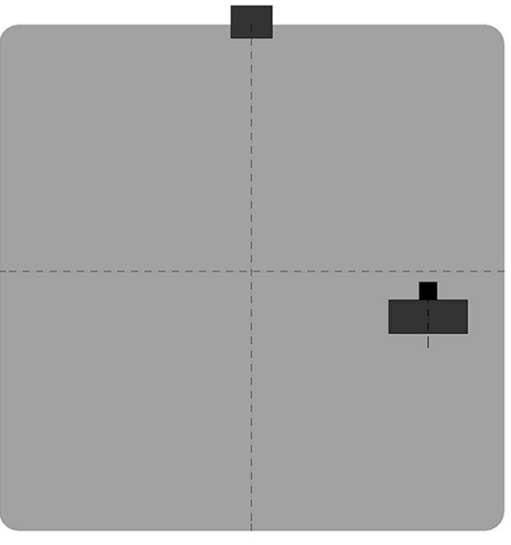

Inchtuthil

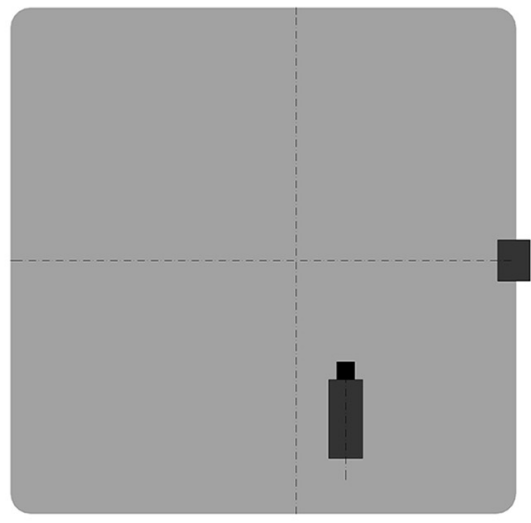

Aquincum

Fig. 7. Schematic plans showing the orientations of the fortresses and the tribunes' houses. Black squares indicate the location of the dining rooms

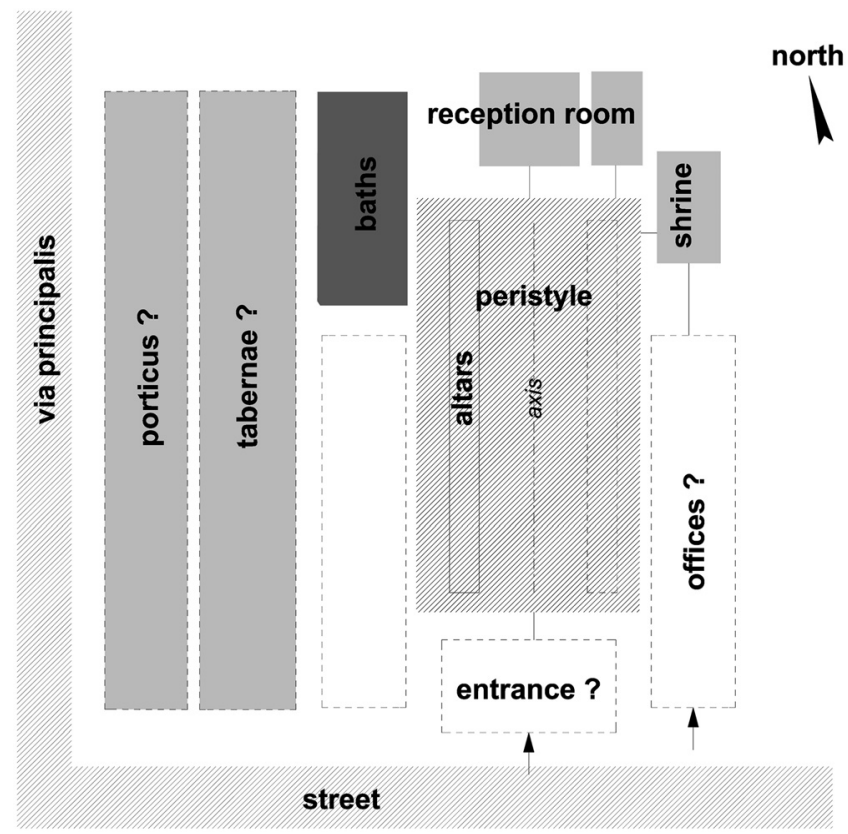

Fig. 8. The House of the Tribunus Laticlavius' proposed floor plan scheme

Though it would be reasonable to assume that the offices of the House of the Tribunus Laticlavius were on the eastern side, connected to the Mithraeum, and the living quarters on the western side, next to the bath, these considerations are hypothetical. Nevertheless, it is still very probable that there was a porticus and a row of tabernae along the via principalis, similar to the houses from Inchtuthil and Vetera.

\section{CONCLUSION}

Although it was excavated only partially, we have enough information to understand the House of the Tribunus
Laticlavius' floor plan. When the house was built, presumably during Hadrian's reign, it followed a model which was the Roman interpretation of the Hellenistic axial peristyle house.

This house type was a novelty in the Early Imperial times and it was also adapted to the some of the buildings of the collegia in the towns. In the legionary fortresses it was reserved for high-ranking officers, especially the tribunes. In the present paper we have compared houses from three fortresses: Vetera, Inchtuthil and Aquincum. The differences between the houses in these fortresses arise from the different orientation of the fortresses that has restricted the free arrangement of the houses' rooms. These restrictions elicited different architectural solutions in these three fortresses. 
What is common in the tribunes' houses in these fortresses is a dining room which faces south and is placed on the axis of a peristyle.

The houses of the tribunes seem to have been modelled after contemporary town houses. We can presume that a house made for a tribunus laticlavius was a copy of a house type that was suitable for someone of the senatorial rank, with office rooms added and adapted to the legionary fortress's street grid and orientation. Such houses must have had important administrative and representative functions.

Because of the alternative datings for the Casa dei Cervi, it is difficult to pinpoint when this type of large, axial peristyle house was introduced into Roman architecture. Nevertheless, the houses from Gaul show that it was popular in the first half of the first century $\mathrm{AD}$, and the examples from Inchtuthil indicate that the design was still current by the end of the first century. The House of the Tribunus Laticlavius in Aquincum was built around the beginning of the second century, and in Severan times it was only remodelled, suggesting that the design seems to have been at least acceptable by the beginning of the third century. We have corroborating information from Gaul, where the house type still flourished, but we also know that it had become outdated around the end of the third century. This sort of cross-dating is very important for the understanding of architectural tendencies, and houses from military contexts provide important details. The chronology of the Roman domus has been worked out in detail for the period covered by Pompeii's existence, and connoisseurs of wall painting styles can give us refined datings for houses from between the first centuries $\mathrm{BC}$ and $\mathrm{AD}$. If we move away from the surroundings of Mount Vesuvius towards the provinces we face great difficulties when trying to assess a house built in the second century AD and in use for centuries, of which not much remains other than foundations which reveal its floor plan. Nevertheless, in our case we have been able to trace the plan of the House of the Tribunus Laticlavius back to a Hellenistic concept which has enabled us to roughly understand its remains and to find its place in Roman domestic architecture.

\section{ACKNOWLEDGEMENTS}

The research reported in this publication was supported by NKFI grants nr. 119520 and 134522.

\section{REFERENCES}

Atlas (1996). Borgard, Ph. (Éd.), La Maison urbaine d'époque romaine en Gaule Narbonnaise et dans les provinces voisines, 2.: Atlas maisons de Gaule narbonnaise. Documents d'archéologie vauclusienne 6/2. Service d'archéologie du conseil général de Vaucluse, Avignon.

Bollmann, B. (1998). Römische Vereinshäuser: Untersuchungen zu den Scholae der römischen Berufs-, Kult- und Augustalen-Kollegien in Italien. Phillip von Zabern, Mainz.
Bonini, P. (2013). Aree scoperte. In: Ghedini, F., and Annibaletto, M. (Eds.), Atria longa patescunt. Le forme dell'abitare nella cisalpina romana. 1-3. Antenor - Quaderni 23. Edizioni Quasar, Roma, pp. 45-70.

Bouet, A. (2001). Les collèges dans la ville antique: le cas des Subaediani. $R A, 32 / 2$ : 227-278.

CAG 13/4 Mocci, F., and Nin, N. (2006). (Éd.), Carte archéologique de la Gaule, 13/4.: Aix-en-Provence, Pays d'Aix et Val de Durance. Éditions de la Maison des sciences de l'homme, Paris.

Desbat, A., Leblanc, O., Prisset, J.-L., Savay-Guerrac, H., and Tavernier, D. (1994). La Maison des dieux Océan à SaintRomain-en-Gal, (Rhône). Gallia suppl. 55. Éd. CNRS, Paris.

Dickmann, J.-A. (1999). Domus frequentata. Anspruchvolles wohnen im pompejanischen Stadthaus. Studien zur antiken Stadt 4. Verlag Pfeil, München.

Fitz, J. (1976). Gorsium-Herculia. Székesfehérvár, István Király Múzeum. George, M. (1997). The Roman domestic architecture of Northern Italy. BAR IntSer 670. Archaeopress, Oxford.

Gros, P. (1983). Statut social et rôle culturel des architectes (période hellénistique et augustéenne). In: Architecture et société. De l'archaïsme grec à la fin de la République. Actes du Colloque international organisé par le Centre national de la recherche scientifique et l'École française de Rome (Rome 2-4 décembre 1980). Publications de l'École française de Rome 66. École Française de Rome, Rome, pp. 425-452.

Gros, P. (1994). Munus non ingratum. Le traité vitruvien et la notion de service. In: Le projet de Vitruve. Objet, destinataires et réception du De architectura. Actes du colloque international de Rome (26-27 mars 1993). Publications de l'École française de Rome 192. École Française de Rome, Rome, pp. 75-90.

Gros, P. (2001). L'architecture romaine, 2.: Maisons, palaces, villas, et tombeaux. Les manuels d'Art et d'Archéologie antique. Picard, Paris.

Kocsis, L. (1991). A Tribunus Laticlaviusok háza az aquincumi 2-3. sz-i legio-táborban (Előzetes jelentés) (Das Haus der Tribuni Laticlavii aus dem Legionslager vom 2-3. Jh. in Aquincum. Vorbericht). BudRég, 28: 117-121.

Lehner. H. (1927). Ausgrabung in Vetera bei Xanten 1926. Gnomon, 3/10: 612-616.

Loustaud, J.-P. (2000). Limoges antique. Travaux d'archéologie limousine, supplément 5. Association Archéologie en Limousin, Limoges.

Madarassy, O. (1991). A Tribunus Laticlaviusok háza az aquincumi 2-3. sz-i legiotáborban: a Mithraeum falfestménye (Das Haus der Tribuni Laticlavii aus dem Legionslager vom 2.-3. Jh. in Aquincum: Wandgemälde des Mithrasheiligtums). BudRég, 28: 123-126.

McKenzie, J. (2007). The Architecture of Alexandria and Egypt, c. $300 B C$ to $A D$ 700. Pelican history of art. Yale University Press, New Haven-London.

Németh, M. (2003). Aquincum castra legionis. In: Visy, Zs. (Ed.), The Roman army in Pannonia. Teleki László Foundation, Budapest, pp. 99-101.

Petrikovits, H. (1975). Die Innenbauten römischer Legionslager während der Prinzipatszeit. ARWAW 56. Westdeutscher Verlag, Opladen.

Pitts, L.F., and St. Joseph, J.K. (1985). Inchtuthil. The Roman legionary fortress. Britannia monograph series 6. Society for the Promotion of Roman Studies, London. 
Raeder, J. (1988). Vitruv, de architectura VI 7 (aedificia Graecorum) und die hellenistische Wohnhaus- und Palastarchitektur. Gymnasium, 95: 316-368.

Richardson, L. (1997). Pompeii. An architectural history. Johns Hopkins University Press, Baltimore-London.

Rouard, E. (1841). Rapport sur les fouilles d'antiquités qui ont été faites à Aix dans les prémiers mois de 1841. Commission d'archéologie d'Aix, Aix-en-Provence.

Rouard, E. (1844). Rapport sur les fouilles d'antiquités qui ont été faites à Aix en 1843 et 1844. Commission d'archéologie d'Aix, Aix-en-Provence.

Szőnyi, E. (2008). Häuser im Munizipium Mursella. In: Scherrer, P. (Hrsg.), Domus, das Haus in den Städten der römischen Donauprovinzen. Akten des 3. Internationalen Symposiums über römische Städte in Noricum und Pannonien. SÖAI 44. Österreiches Archäologisches Institut, Wien, pp. 235-250.

Thomas, E.B. (1955). Die römerzeitliche Villa von TácFövenypuszta. ActaArchHung, 6: 79-152.

Timár, L. (2011). The spread of the Roman domus-type in Gaul. BAR IntSer 2206. Archaeopress, Oxford.

Vipard P., Fauduet I., Graham B., and Odenhardt-Donvez I. (2007). Maison à péristyle et élites urbaines en Gaule sous l'Empire. Gallia, 64: 227-277.

Wallace-Hadrill, A. (1994). Houses and society in Pompeii and Herculaneum. Princeton University Press, Princeton. 